UNTAG Law Review (ULREV)

Volume 2, Issue 2, Nov 2018, PP 131-143

ISSN 2549-4910 (online) \& ISSN 2579-5279 (print)

http://jurnal.untagsmg.ac.id/indeks.php/ulrev/indeks

www.fakhukum.untagsmg.ac.id

\title{
RECONSTRUCTION OF LEGAL CULTURE OF POLITICAL PARTY IN RECRUITMEN OF LEGISLATIVE MEMBERS WITH GENDER EQUALITY
}

\author{
Baharudin \\ Student Of Doctoral Program Diponegoro University \\ Lecturer at Faculty of Law University of Bandar Lampung
}

\begin{abstract}
The legal culture of political parties in the recruitment of legislative candidates with gender law in Bandar Lampung City is based on a "legal culture" to reveal the legal culture of political parties in the recruitment of legislative candidates with gender equality. The problem: What is the legal culture of political parties in the recruitment of legislative policies that have gender justice, namely the recruitment of legislative candidates not yet gender justice. How to build an ideal community culture in recruiting legislative candidates with gender equality. This study uses the constructivism paradigm, the socio-legal research approach, which is analyzed by Struss and Corbin models. The round of this study: 1. Political parties appear in recruitment and legislative legislation has not yet been adopted in the legal culture, because it still separates women's rights. 2 . The legal culture of political parties in the recruitment of legislative candidates has no gender, which is caused by the factors of political parties participating in the election that are still recruiting and in accordance with patriarchal ideology, 3 . The ideal legal construction of political parties in recruiting legislative candidates with gender equality, namely recruiting legislative candidates must be fair, not separate women's political rights to be nominated or appointed as legislative candidates in general elections, fulfill legal requirements, not only fulfill $30 \%$ representation of women, must be prepared through cadres, education and training, have become members of a political party of at least 6 months to 1 year, noble, loyal, dedicated, and loyal to Pancasila and the 1945 Constitution of the Republic of Indonesia.
\end{abstract}

Keywords : Legal Culture Of Political Party, Recruitment Of Legislative Candidates With Gender Equality.

\section{INTRODUCTION}

Democracy has relevance to the theory of popular sovereignty, even if it is traced that the meaning of democracy itself comes from the word demos meaning people and kratein which 
means power. This means that the people become the most authoritative parties to direct the implementation of state power. Democracy has now become a large current that swept the world, so it is considered as the most popular system and considered the best system in regulating the relationship between the people and the authorities ${ }^{1}$ One of the instruments in a democratic country is the election. ${ }^{2}$

Elections are a must to uphold the democratic order to elect the House of Representatives, the Regional House of Representatives, the President and the Vice President, as well as the Regional Representative Council. The election is stipulated in the 1945 Constitution, Article 22E Paragraph (1) which states that Elections shall be held in a direct, public, free, secret, honest and fair manner every five years. Paragrap jadi nh (2) Elections shall be held to elect members of the People's Legislative Assembly, the Regional Representatives Council, the President and the Vice-President and the Regional People's Legislative Assembly. Paragraph (3) The election participants to elect members of the People's Legislative Assembly and members of the Regional People's Legislative Assembly shall be political parties. As for the function of Political Parties as regulated in Amendment of the Law of the Republic of Indonsia no. 2 of 2008 on Political Parties, is contained in Article 11 paragraph (e) which states:"Political recruitment in the process of filling political office through the mechanism of democracy by taking into account gender equality and justice".

The election to elect legislative candidates (DPR), DPRD and DPD, is further stipulated in Law Number 8 Year 2012 regarding General Election, in which each political party has the authority to recruit legislative candidates either at the central or regional levels. Furthermore, the procedure for recruitment of candidates for legislative members, by political parties both at the central and regional levels, is regulated in Law no. 8 of 2012 Article 52-56 stating that: that the candidate selection of prospective legislative members is a political party at each level of its territory. be democratic, and open in accordance with the articles of association, bylaws, and / or internal regulations of participating political parties. The list of prospective candidates as referred to in Article 53 shall contain at least 30\% (thirty percent) of women's representation. Election results in 2014, more male members of the House of Representatives, few women DPR members. Further the facts can be seen in table 1.1, and table 1.2 :

1 Fitra Arsil dalam : Mencegah Pemilihan Umum Menjadi Alat Penguasa “Jurnal Legislasi Indonesia Vol 9 nomor 4 Desember 2012, hlm 563.

2 A. Mukhthie Fajar dalam "pemilu yang Demokratis dan Berkualitas, Penyelesaian hukum Pelanggaran Pemilu dan PHPU, Jurnal Konstitusi. Volume 6, Nomor 1, April 2009, hlm 4. 
Table 1.1

Composition of Legislative Council Members in 2009

\begin{tabular}{|c|c|c|c|c|}
\hline No & Name & Male / \% & Female / \% & Amount \\
\hline 1 & House of Representatives & $456 / 81,45 \%$ & $104 / 18,6 \%$ & 560 \\
\hline 2 & DPRD Lampung Province & $79 / 8 \%$ & $20 / 21 \%$ & 90 \\
\hline 3 & DPRD Kota Bandar Lampung & $39 / 80,7 \%$ & $6 / 13.3 \%$ & 45 \\
\hline
\end{tabular}

Data Source: Election; Central, Province, and City Election Commission. ${ }^{3}$

Table 1.2

Composition of DPR, Provincial DPRD and

Bandar Lampung DPRD Members in 2014

\begin{tabular}{|c|c|c|c|c|}
\hline No & Name & Male / \% & Female / \% & Amount \\
\hline 1 & House of Representatives & $4003 / 81,45 \%$ & $97 / 17,32 \%$ & 560 \\
\hline 2 & DPRD Lampung Province & $63 / 79 \%$ & $17 / 21 \%$ & 80 \\
\hline 3 & DPRD Kota Bandar Lampung & $45 / 90 \%$ & $5 / 10 \%$ & 50 \\
\hline
\end{tabular}

Data Source: Election Commissionof Kota Bandar Lampung ${ }^{4}$

The facts of election results in 2014 above male legislative members are more than female legislators. This is due to the recruitment pattern of legislative candidates by each political party participating in the election, not yet gender perspective. The gender perspective in the recruitment of legislative candidates means that it does not give priority to men rather than women. In addition, due to the recruitment patterns of legislative candidates have not been gender equitable. According to Agnes Widanti the law of gender justice is the law (both state law and society law or community norms) which allows dynamic balance between men and women in power structures in society and State. These structures are found in political economy, law and ideology. ${ }^{5}$

Elections are a real form of procedural democracy, although democracy is not the same as elections, but elections are one of the most important aspects of democracy that must also be democratically organized. Therefore, it is usual in countries calling themselves democracies to choose the elections to elect representatives of the people who will sit legislatively in both the

3 Data diunduh Tanggal 10 Juli, 2015.

4 Data diunduh tanggal 7 Juli 2015.

5 Agnes Widanti, Hukum Berkeadilan Gender, Penerbit, Buku Kompas, Jakarta, 2005, hlm 62. 
central and regional levels. Democratic democracy and elections are "qonditio sine qua non", the one can not exist without the others. (one can not exist without anyone else). government requires the consent of the governed can be associated. In fact, in most democracies, elections are regarded as symbols, as well as the benchmarks of democracy itself. In other words, elections are a logical consequence of the adoption of democratic principles in the life of the nation and state. The basic principle of democratic state life is that every citizen has the right to participate actively in the political process.

According to Hamdan Zoelva that in order to ensure the realization of elections that are in accordance with the principles of democracy, the implementation must be done with a good system, namely the existence of very important parts, such as electoral regulation, electoral process, and electoral law enforcement. ${ }^{6}$

Electoral regulation is any applicable provisions or rules regarding General Election, binding and a guide for organizers, candidates and voters in fulfilling their respective roles and functions. Electoral process is all activities directly related to the implementation of elections refer to legal provisions both legal and technical. Electoral law enforcement is a law enforcement of political, administrative, or criminal election rules. Fulfillment of the three parts of the election strongly determines the extent to which the capacity of the system can bridge the achievement of goals and election processes, each section can not be separated because it is a unified whole. ${ }^{7}$

Political parties participating in the election in recruiting legislative candidates in the 2014 election in Bandar Lampung city, in fact still rule out women legislative candidates, in terms of election laws and legislation of political parties have regulated the political rights of women. This is due to the behavior of political party officials in the process of recruiting, selecting and appointing legislative candidates not to be carried out in a democratic and open manner in accordance with Articles of Incorporation, Bylaws, and / or internal regulations of participating political parties.

The governance of political parties that are not gender-based is due to the dynamic imbalance the relationship between men and women is a social injustice. It means injustice caused by power structures in society. These structures are in the legal and political fields. ${ }^{8}$ the existence of social construction concerning male discrimination against women's participation in economy and politics. So it implies on the level of practical political life, the law and the rights

6 Hamdan Zoelva, dalam Problematika Penyelesaian Sengketa Hasil Pemilu kada oleh Mahkamah konstitusi" Jurnal Konstitusi, volume 10, Nomor 3, September 2013, hlm 381.

7 Bisariyadi, ,dalam "Koparasi Mekanisme Penyelesaian Sengketa Pemilu di beberapa negara Penganut Paham Demokrasi Konstitusional, Jurnal Konstitusi Volume 9, Nomor 3, September 2 hlm 536.

8 Agnes Widanti, Op Cit. 
of citizens. According to Ratna Megawangi, gender role difference in Indonesia is due to social construction process. In many ways gender role differences are conditioned by the patriarchal Indonesian society. According to ${ }^{9}$ Ratna Megawangi the mopinion of Ratna Megawangi mentioned above, the difference of gender position and role in Indonesia due to social construction, and still dominated by the patriarchal society order, this can change through mutual agreement, even the role and position of women, gender equality and feminist are placed in the context empowering each gender's potential to function properly, functioning complementarily.

The above conditions, in terms of the legal culture of Political Parties in the recruitment of legislative candidates with gender equality, will objectively be beneficial to women. If the recruitment of legislative candidates is not with a gender equitable legal culture, it will be detrimental for women in following the nomination process of legislative members.

According to Susi Dwi Harijanti, a woman's rights often get obstacles in politics, including election matters, decision making, and state administration and governance. When moral rules are no longer effectively used to prevent human rights violations, then law must play a role to define boundaries and obligations that must be obeyed against others. ${ }^{10}$ Furthermore, he said that according to Law Number 2 Year 2012 on Political Parties, that there should be the 30\% quota of women representation in legislative candidacy, but in practice, it shows the form of patriarchal ideology is always repeated in law. ${ }^{11}$

Based on the above background, the legal culture of political parties in the recruitment of legislative candidates with gender justice needs to be constructed the new (ideal) one through, values, and attitudes related to the law, which determine when, why, and how the community obeys legal or otherwise denying the law, determiniing what legal structure is used and what is the reason, and what legal rules are chosen to apply or be ruled out. ${ }^{12}$ This resulted in the tendency to ignore, disrespect and disbelief of the people against the law. ${ }^{13}$ The indication of the legal culture of political parties in the recruitment of legislative candidates with gender equality must apply the legal culture of political parties that is to apply attitudes, values and behaviors, not merely put forward the aspect of legal certainty, regardless of the aspect of justice, and benefit.

9 Ratna Megawangi, Membiarkan berbeda, Sudut Pandang Baru Tentang Relasi Gender, Bandung, Nizan Pustaka, 1999, hlm 103.

$10 \mathrm{Hhtp} /$ galeri, psi.id/koran-solidaritas/item/95-mendobrak-tabu-gender.

11 Ibid.

12 Lawrence M. Friedman, Legal Culture, and Social Devlopment, dalam Lawrwnce dan Stewart Maucauay, (eds) Law the Bihovioral Science, Indianan Polis, The Bobbs Merril Company, h 1000-17.

13 Sultan Hamengkubuwono ke X, Merahut Kembali Keberhasilan Kita, PT Gramedia Pustaka Utama, Jakarta, 2007, hlm 275. 


\section{Main Problems}

Based on the background of the above problem, it can be drawn some problems in this study, namely:

a. What is the legal culture of political parties in the recruitment of legislative candidates relating to gender justice.

b. Why is the legal culture of political parties in the recruitment of legislative candidates not yet gender equitable.

c. How to construct an ideal legal culture of political parties in the recruitment of legislative members who are gender equitable.

\section{Discussion}

\section{Political Culture of Political Parties in Recruitment of Legislative Cabdidates Related to Gender Justice.}

The political parties participating in the 2014 election are as follows: 1. Golkar Party, 2. PDI Perjuangan,3. Democrat Party, 4. Hanura Party, 5. PKB, 6. PPP, 7. PAN, 8. Nasdem Party 9. PKS, 10. Gerindra Party 11. PKPI, and 12. Bulan Bintang Party. The political parties participating in the 2014 election have recruited and enacted women legislative candidates, fulfilling the provisions of the law, which has fulfilled the representation of $30 \%$ women, this is all done in the framework of affirmative action, encouraging women to be legislative members. However, political parties participating in the election, in recruiting and appointing legislative candidates have not been through party cadreisarial mechanisms, education and training of party cadres, ie small parties such as the PPP and PKPI, this is due to the weakness of the budget to conduct these activities.

In addition, the recruitment of candidates for legislative members is not through good stages, recruitment of candidates is only instantaneous, they arrange some activities to prepare and recruit cadres for candidates for legislative members just before the general elections. Political parties should prepare their party cadres, through the stages, which are swayed through party cadre, so that each party participating in the election has qualified cadres to be nominated, including female cadres. If the regeneration is not done this will cause the shortage of qualified women cadres to be nominated, and the party will eventually nominate female cadres just to fufill the $30 \%$ quota of women representation. This is also what can result in the election of small number of women when compared to male legislative candidates. In Bandar Lampung women who become members of the legislature are only 5 people, from the number of legislative members proposed 50 legislative candidates set in general elections in 2014. Male elected legislative members amounted to 45 people. 


\section{Construction of the Legal Culture of an Ideal Political Party in the Recruitment of Candidates for Members of the Legislative with Gender Justice.}

Suprastructure of a political party is a party official at the city level of Bandar Lampung which is stipulated in the management bord of the party officials of the city, sub-district branches, to the vilage level. All party management boards are established legally, set in a letter signed by the party chairman and secretary based on management board level. Suprastructure of political parties in each field have the duty and authority in implementing party programs, to succeed the ideals of the party, for the benefit of the people and the state.

For the superstructure of political parties, it is necessary to develop its legal culture, that is, the political attitudes which have the attitude, the values which are considered good by the people, do not impose their will (authoritarian), should be responsive in all actions and decisions. Political infrastructure is a state institution, which has neutral functions and duties, such as media, public opinion, social institutions, customary institutions (traditional leaders and religious leaders). Political infrastruture serves to provide good input, criticism and suggestions so that suprapolitical party structure can carry out its duties and functions well when the process of recruiting legislative candidates with gender justice.

\section{Legal Culture of Political Parties in the Recruitment Process of Legislative Candidates Based on Gender Justice}

This research is intended to find a new paradigm in applying the legal culture of political parties, which means there will be an ideal legal cultural construction of political parties in the recruitment of legislative candidates with gender equality. The basic idea underlying the new construction of the application of ideal political party legal culture in the recruitment of legislative candidates for gender equality is based on Law No. 8 of 2012 on elections, namely in accordance with articles 51 to 56 , how to recruit legislative candidates to meet the requirements and completeness, and correctness of the designated administration.

The substance of the above-mentioned Constitutional Law is good, which is related to the terms of recruitment of legislative candidates, but in practice the recruitment pattern of political parties participating in the 2014 election is not yet all of a gender perspective. The gender perspective here is meant not to distinguish women's political rights, equal positions and roles between men and women in law (equality before the law). Legal culture should be applied in the recruitment of legislative candidates with gender equality but the reality shows that the law is changedand is not in accordance with the rules. The law only reinforces patriarchal social relationships. The relationship is based on the behavior of values, the moral power of men and disregarding the position of the women's experience, because women themselves have souls, or the sense that their practical application is just or unfair. 
This is caused by legal culture factor of patriarchal party structure in recruiting legislative candidate, resulting in unfair recruitment pattern. Facts of interview result with informant of political party participant of election, public figure, woman figure, adat or traditional informal leader thatpolitical parties participating in the election, recruiting women legislative candidates have fulfilled 30\% representation of women with the real purpose is affirmative action, encouraging women to succeed sitting in legislative body, not just political parties pass the election.

Besides the legal culture of political parties in the recruitment of legislative candidates, no gender perspective is influenced by indigenous culture of Lampung, which only supports the leadership of the patrinial kinship line, male lineage, not for women. The legal culture of political stereotypes in the recruitment of legislative candidates with gender equality should be constructed, using responsive legal theory of Philipe Nonet and Philipe Selznik, explaining there are three types of legal character, namely repressive, autonomous and responsive. Repressive law is a tool of power that aims to impose (repressive) desire of the authorities (power). The repressive law aims to uphold justice through a power approach, when it is associated with a political party that is the holder of the political power of electoral participants in recruiting legislative candidates, only with patriarchal power for the benefit of men, forgetting the position and role of women. Autonomous law is an attempt to uphold justice independently or independently without intervention and intervention by anyone and from anyone. While responsive law is a means of responding to the reality of the needs and phenomenon of the aspirations of society, so the law develops in accordance with the wishes of the community. Thus, the legal process develops gradually which will definitely bring about evolutionary change. Evolutive in responsive law starts from an ideal type (repressive), less ideal (autonomous) to the most ideal (responsive) type.

Thus, the legal culture of political parties in recruiting candidates for legislative members should be responsive on the basis of democracy and openness and aspiration, based on the wishfulness of the conscience of women, not discriminating the political rights of women to vote and be elected in the general election, the role of women, has the same rights as men in the rule of law. Electoral political parties make careful planning, in the recruitment of candidates for legislative members, must apply a gender responsive legal culture, based on the attitude, the behavior of political parties, the values and the views of a good society. Political parties participating in general elections, recruiting legislative candidates, must be in accordance with the provisions of the 1945 Constitution, article 27 guarantees rights between men and women. Indonesia has ratified the Convention on the Elimination of All Forms of Discrimination Against Women through Law Number 7, 1984. Women's political rights set forth in Article 7 include: 
a. The right to elect and to be elected

b. The right of participation in decision making

c. The right to hold office in government and execute every functions of government at all levels.

d. Participate in organizations and associations;

e. Participate in relevant non-governmental associations with public life and state politics.

Political parties in recruiting and appointing legislative candidates with gender justice need to set rules in their internal regulation or $\mathrm{AD} / \mathrm{RT}$, such as the stipulation that the candidate has been a member of the party participating in the election at least 6 months and maximum 1 year. This rule is intended, so as not to discriminate in recruiting and appointing legislative candidates. The reconstruction of legal culture in the recruitment of legislative candidates with gender justice, using Aristotle's theory of justice, the legal culture of the behavior of the Political Party structure in accordance with the ethical social feelings, does not harming others arbitrarily, gives to all its own part, namely how to recruit and assign legislative candidates to the same position, in the distribution of powers of political power, in terms of recruiting and providing fair treatment to men and women.

According to Aristotle, ${ }^{14}$ without any good ethical social inclination to the citizen, there is no hope for the highest justice in the state, even if a wise one rules with any law. Since the law binds all people, legal justice must be understood in the sense of equality. But he shares the numerical equality and proportional equality. Numerical equality generates the principle of "all men equal before the law". While proportional equality generates the principle of "giving each person what is his right". Aristotle put forward another model of justice, namely distributive justice and corrective justice. Distributive justice is identical to justice on the basis of proportional equality. While corrective justice (remedial), focusing on the wrong correction. If an agreement is violated or an error is committed, then corrective justice seeks to provide adequate compensation to the injured party. Corrective Justice is in charge of rebuilding equality.

Nasaruddin Umar defines gender as a concept used to define male and female differences in terms of socio-cultural; gender in this sense defining men and women from non-biological angles. ${ }^{15}$ According to Ratna Megawangi, gender role difference in Indonesia is due to social construction process. In many ways gender role differences are conditioned by the patriarchal Indonesian society. According to her, are these natural? I do not think so. They can be changed

14 Bernard L. Tanya, Yoan N. Simanjuntak, Markus Y Hage, Teori Hukum Strategi Tertib Manusia Lintas Ruang dan Generasi, Yogyakarta, Genta Publishing, 2010,hlm. 45.

15 Nazarudin Umar,Argumen Kesetaraan gender perspektif Al-Quran Jakarta, Dianan Rakyat,2010, hlm 31. 
by mutual agreement. ${ }^{16}$ Based on the above facts, if a woman is willing, serious in her struggle, will bring results also, achievedher goals. Allah SWT is fair to his servants, Allah says in the Qur'an (Q.S: 13: 11) God will not change the state of a people, so that the people will change their own circumstances.

Since the passing of the provisions of the "30\% women's quota in Law No. 8, 2012 on general elections, marks the significant achievement of many years of women's affirmative action movement to sit as legislators at various levels, such as central, provincial and regency/city levels. The presence of women in the political world is a prerequisite for the realization of a society that has gender equality and justice. In short, the need to increase women's representation in political institutions in Indonesia, thus raising an awareness that all political priorities and agendas must be overhauled and they can not be achieved with traditional political systems. If women want to come forward and hold various public positions, undoubtedly they will be able to build and establish new social and economic values that suit their interests.

The increasing representation of women in political institutions means at the same time also political decisions that will ensure the rights of their groups and the wider community and allocate the resources necessary to improve the quality of human life. Recruitment of legislative candidates with gender equality is recruitment that does not distinguish gender. Gender justice means it does not distinguish gender, whether the candidate is male or female is equal before the law. Gender equity is a fair process and treatment of women and men. Gender equity means that there is no role standardization, double burden, subordination, marginalization of women and men. ${ }^{17}$ The realization of gender justice is characterized by the absence of discrimination between women and men in obtaining the position to become a legislative member as a representative of the people.

Justice in Islam, as told Ibn Jubayr, is that justice that will be realized is justice which is in line with the words of God, fulfill the priciples of propriety, do not harm others, able to save themselves and must be born of good faith. ${ }^{18}$ Islamic justice bases itself on moral ethical principles and always seeks to realize group justice. Thus, justice in Islam bases itself on moral-ethical principles and always seeks to realize substantial justice by realizing individual and group happiness, outward and inner happiness of life, and happiness both in the world and the hereafter. The development of national law will not work properly, if seen from the substance of the law is not good. The process of determining legislative candidates which

16 Ratna Megawangi, Op Cit.,

17 Satya Arinanto, Op Cit,

18 MahmuTarom, Rekonstruksi, Konsep Keadilan (studi tentang perlindungan Korban tindak pidana terhadap nyawa menurut Hukum Islam, konstruksi masyarakat dan instrumen Internasional, Semarang Universitas Diponegoro, 2010, hlm 90. 
prioritizes procedural justice is what makes most women will experience disappointment and disadvantaged and will ruin democracy. This will make the party power holders tend to be authoritarian, and in determining the legislative candidates they will be elitist or orthodox, not democratic / responsive.

According to Esmi Warassih ${ }^{19}$ the issue of justice is a complicated and complex problem, because it concerns the relationship between people from all aspects of life. Understanding justice becomes clear, if we first understand the law. In essence the law always contains abstract values. The basis for the law is to regulate human behavior; which unes are allowed and which should not be. What are the criteria here ? In this case the law used is not sufficient because it isthe juridical basis only It needs to be equipped with philosophical foundations and sociological foundations because justice is not something that is obtained only through the process of reasoning or logic but also something that can be obtained completely. ${ }^{20}$ The law has dimensions of moral ethical values embodied in the principles of law and set forth in the norms and formulated in the rules. Therefore, a political party leader in determining prospective legislative candidates, is not sufficiently implemented with democratic and statutory rules legislation, but with a legal culture containing the values, morals, behaviors, attitudes and expectations of the community.

Furthermore, Esmi Warassih explained that the face of justice is multidimensional. In the rule of law, it depends on the law enforcers, which side they approaches the law. In the legal state of Pancasila, for the concept of legal justice, they want to cover by the term "that is Justice by virtue of the One Supreme God". ${ }^{21}$ Justice here should have a perfect meaning because justice is not only about the distribution of resources but must refer to morality issues. The application and implementation of justice should be seen from all aspects as the execution of a religious worldly life. This is related to the ideal political party legal culture in recruiting legislative candidates in addition to paying attention to gender equity, it is necessary to pay attention to the education qualification of legislative candidatesi.e. in terms of education the candidates should be at least bachelor / strata one graduates. Political parties need to consider the environment aspect of the legislative candidates, both internally and externally. Internally, political parties establish women legislative candidates from party cadres who have been proven to be devoted, faithful, disciplined and non-disable by law, and political parties must establish candidates on condition that they have become party cadres for at least the last 5 years.

19 Esmi Warassih, Pemberdayaan Masyarakat Dalam Mewujudkan tujuan hukum Islam (proses penegakana hukum dan persoalan keadilan "Pidato Pengukuhan Guru besar dalam Ilmu hukum pada Fakultas Hukum (universitas Diponegoro, 14 pril 2001, hlm 34.

20 Esmi Warassih, Op Cit,

21 Ibid, 34. 
In determining women candidates, political parties alsoprioritize the candidates who have shown seriousness even though women have a dual function. Political parties in appointing women legislative candidates are not affected by patriarchical Lampung culture or custom, and not only concerned with male legislative candidates rather than female legislative candidates. In addition, political parties recruits and determines women legislative candidates who have won public confidence in each electoral district where she is placed, so she will get a good response from the community.

\section{Closing}

1. The legal culture of political parties participating in general elections in the recruitment of legislative candidates has not been gendered justice. Since the practice of recruitment of legislative candidates has not been gender perspective, political parties in recruiting and appointing legislative candidates are still discriminatory, not based on fair women's political rights, not take into account the wishes and experiences of women.

2. Legal culture of political parties in the recruitment of legislative members has not been gender-based. It is caused by several factors, such as the legal culture of political parties at the level of the Branch Executive Board (DPC) or at the level of the Regional Executive Board (DPD II), in the process and implementation of recruitment and determining candidates for legislative members, are not yet based on gender-equitable decisions, undemocratic and not open and not based on good behavior, values and community views.

3. Ideal reconstruction of legal culture of political parties in recruitment and determining candidates of legislative members with gender equality is applying legal culture of political party in recruitment of legislative member candidates by applying fair recruitment process, integrity, transparency and accountability, and are based on alignment to women and do not distinguish the political rights of women legislative candidates in the election.

\section{BIBLIOGRAPHY}

\section{Books}

Agnes Widanti, Hukum Berkeadilan Gender, Penerbit, Buku Kompas, Jakarta, 2005

Arinanto Satya, Ninuk Triyanti, 2009, Memahami Hukum dari Konstruksi Sampai Implementasi, Jakarta: Rajawali Pers, Divisi Buku Perguruan Tinggi, PT. Raja Grafndo Persada.

Bertalanffi, Ludwing von, 1991, General System theory, Foundation Development Aplication, Penguin Boooks Midlesex. 
Charles Sampford, 1999, The Disorder of Law : A Critique of Legal Theory, Brasil Balckwell, New York,

Daniel S. Lev. 1990, Hukum dan Politik di Indonesia, Kesinambngan dan Perubahan, terj. Nirworo dan AE. Priyono, Jakarta, LP3ES,.

Darji Darmodiharjo dan Shidarta. 1996, Penjabaran Nilai-nilai Pancasila dalam Sistem Hukum Indonesia. Jakarta: PT Raja Graflndo..

Esmi Warassih, Pemberdayaan Masyarakat Dalam Mewujudkan tujuan hukum Islam (proses penegakana hukum dan persoalan keadilan "Pidato Pengukuhan Guru besar dalam Ilmu hukum pada Fakultas Hukum (universitas Diponegoro, 14 pril 2001

MahmuTarom, Rekonstruksi, Konsep Keadilan (studi tentang perlindungan Korban tindak pidana terhadap nyawa menurut Hukum Islam, konstruksi masyarakat dan instrumen Internasional, Semarang Universitas Diponegoro, 2010.

Scale, Ann, 2006, Legal Feminism Activism, Lawyering, and Legal Theory, New York, University Press,.

Soecipto ,Ani, 2011, Politik Harapan Perjalanan Politik Perempuan Indonesia Pasca Reformasi, Jakarta, P.T. Wahana Aksi Kritika,.

Tamanaha Brian Z., 2010, General Jurisprudence of Law Society, (Oxford, Oxford), University Press.

\section{Papers/Articles/Journals}

Fitra Arsil “mencegah Pemilihan Umum Menjadi Alat Penguasa, Jurnal Legislasi Indonesia, Vol. 9 No.4 Desember 2012.

Zoelva, Hamdan, "problematika Penyelesaian Sengketa Hasil Pemiliukada oleh Mahkamah Konstitusi”,Jurnal Konstitusi, Volume 10 Nomor 3, September 2013. 